Canadian Journal of Family and Youth, 14(1), 2022, pp. 162-179

ISSN 1718-9748@ University of Alberta

http://ejournals,library,ualberta.ca/index/php/cjfy

\title{
Marital Adjustment and Communication Styles among Married Adults in Ilorin, Kwara State, Nigeria
}

\author{
Falilat Anike Okesina, $\mathrm{PhD}$
}

E-mail: okesina.fa@unilorin.edu.ng

\begin{abstract}
This study examined the marital adjustment and communication styles among married adults in Ilorin, Kwara State, Nigeria. A descriptive survey design was adopted. The population consists of married adults in Ilorin, Kwara State. Two research questions were raised and four null hypotheses were postulated in the study. Data were collected using a questionnaire tagged 'Relationship between Marital Adjustment and Communication Styles Questionnaire' (RMACSQ). Data analysis was done using Pearson's Product Moment Correlation (PPMC). The result obtained revealed that there was a high level of marital adjustment among married adults in Ilorin, Kwara State. Married adults in Ilorin Kwara State adopt good communication styles in marriage. There was no significant relationship between marital adjustment and communication styles of married adults in Kwara State based on age, gender and educational status. There was a significant relationship between marital adjustment and communication styles among married adults in Kwara State on the basis of years of marriage. Based on the findings of this study, it was recommended that seminars and conferences should be organized for married adults in other to enlighten them on the challenges of marital relationships. This would enable them to adjust and communicate better in their new home.
\end{abstract}

Keywords: marital adjustment, communication styles, married adults, Ilorin

Okesina, Falilat Anike Ph.D., is a senior Lecturer in the Department of Counsellor Education, University of Ilorin, Nigeria. She obtained her Doctor of Philosophy (Ph.D.) (2012) in Educational Guidance and Counselling from the University of Ilorin, Nigeria. Okesina is a registered teacher with the Teachers' Registration Council of Nigeria (TRCN). She is a member of Counselling Association of Nigeria; member, Association of Professional Counsellors in Nigeria. 
She is currently the Ag. Director, Unilorin Counselling and Human Development Centre, University of Ilorin. Her research interests include marital/family life counselling; school counselling; and rehabilitation counselling. Recent publications include: Adegboyega, L. O., Okesina, F. A. \& Jacob, O. A. (2017). Family relationship and bullying behaviour among students with disabilities in Ogbomoso, Nigeria. International Journal of Instruction, 10(3), 241-256; Odebode, A. A. \& Okesina, F. A. (2017). Expectations of patients towards health care: A case study of Nigeria and Canada. Pakistan Journal of Professional Psychology and Practice, 8(1), 28-44; and Oniye, A. O., Odebode, A. A. \& Okesina, F. A. (2018). Marital breakdown and socio-emotional development of adolescents in Ibadan metropolis, Nigeria. Canadian Journal of Family and Youth, 10(1), 191-204. 


\section{Introduction}

It is necessary for most individuals in Nigeria to choose a marital partner, especially among traditional and family settings. It is an essential phenomenon in human life irrespective of tribe, society and religious affiliation. In the opinion of Munroe (2003), marriage is a religious duty and is consequently a moral safeguard as well as a social necessity. The assumption for its social necessity is rested on the premises that through it, families are established and the family is the fundamental unit of human society.

There are numerous definitions of the term 'marriage', the same way there are different impressions about what marriage as a concept connotes (Tolkien, 2005). According to Habeeb (2005), marriage is defined as a relationship involving two or more people of the opposite sex, whose relationship is expected to endure beyond time. It is further explained that marriage is the union of one man and one woman for their mutual help and happiness, procreation and child rearing until death.

In seeking to attain a greater understanding of the light and context surrounding the dissolution of marriage, researchers have also discovered that approximately two-thirds of the couples that divorce will do so within the first ten years of marriage (Clark, 1995). In the same vein, Cohn (2010) reported that in United States of America, the rate of divorce in the 2001 survey was forty-one percent for men who were between ages 50-90 and 39 percent for women in the same age group. Also, about sixty percent of all marriages that eventually ended up in a divorce occurred within the first twenty years of marriage.

Marriage is a legal union between a man and a woman as husband and wife, which further connotes matrimony, wedlock, alliance, association and union (Ariyo, 2005). Deducing from the definitions given above, certain purposes that constitute marriage are unveiled as follows: companionship, social integration of persons, approved sexual union, mutual commitment, mutual growth, bridging of the gender gap and promoting the birthright of children. National polls showed that what people consider being very important in marriage (that is, love, sexual fidelity and ability to talk about feelings) have been fairly similar over the past two decades (Roper Organization, 1990). It was also found that a person's beliefs about marriage and how marital satisfaction was achieved might significantly affect one's expectations and readiness for marriage (Akpan, 2002).

In Nigeria, more than ten percent of the marriages conducted every year, ended up in divorce (Adeyemi, 1991). The number had since risen, according to Esere (2008). Yahaya (2008) found that in Nigeria, twenty percent of the marriages conducted yearly ended up in divorce or separation. Esere (2008) noted that about forty percent of the marriages contracted every year in Nigeria end up in divorce or separation. Ogunsanmi (2008) also indicated that people who marry young are likely to divorce at relatively young ages because, a person who marries young is cognizant of his chances of remarriage in case of divorce. This makes them not to be tolerant in their marriages. Ogunsanmi (2008) and Yahaya (2008) revealed that age at marriage does have a substantial impact on marital satisfaction and stability.

According to Verderber and Verderber (2004), communication can be referred to as the process used by people to create and manage relationships. DeFrain (2000) described communication as the heart of an intimate human relationship and the foundation on which all 
other relationships are built; they also assert that it is the key to a successful couple relationship. In fact, the ability and the willingness to communicate have been found to be among the most important factors in maintaining a satisfying relationship. Studies reveal that the top five issues generating conflict in marriage are money, family, communication, household tasks and personal taste (Anyakoha \& James, 2004; Ekot \& Usoro, 2006).

A feature common to many problems in marriage is a lack of communication between the partners (Esere, 2008). The transition from the joy and affection and mutual concern of courtship to the realities of marriage can sometimes be traumatic (Yahaya, 2008). Some men and women come to feel that marriage is a "trap", into which they were led by the romantic expectations of the courtship, but from which afterwards they long to "escape". After marriage, some men seem to see no further need for showing signs of affection or tenderness, no need for conversation or sharing (Oniye, 2002; Yahaya, 2008). Omotosho (1994) opined that, in some homes, words are rarely exchanged except in anger, in nagging, or in demand. Sometimes the main, if not the sole communication between married adults is through their children.

The ability of a relationship to adjust, to take into account the changing needs of its members hinges on communication Over the last twenty years, marital therapists, especially those working from the behavioural and cognitive behavioural model, have placed a strong emphasis on the relationship between communication and marital satisfaction (Gordon, Baucom, Epstein, Burnett, \& Rankin, 1999).

However, most people enter into marriage with the right expectations of joy and happiness with the full sense of accomplishing the purpose for which marriage is established. This is corroborated by Esere (2002) who indicated that marriage is usually contracted amidst joy, happiness and merry-making for the couple, family members and friends. Findings suggest that a happy marriage is conducive to a long, healthy life (Waite \& Gallagher, 2000). The researcher then wonders why the joy of marriage could turn sour suddenly. This experience by a couple may be because they lack the ability to face the challenge and problems that arise and/or they are yet to understand the factors that favour marital satisfaction. The reality of it is that each marriage has its own unique challenges and problems.

Communication seems to be an integral part of marital adjustment. It serves as a mainstream that cuts across all other areas of adjustment in marriage. Relating to one another in a marital relationship is inevitable because men in Nigeria are gregarious in nature. However, two people may be living together under the same roof and may refuse to communicate with each other. This is supported by Cohn (2010) who asserted that unless two people who are living together tune into each other's wavelength, they might be (psychologically) miles apart. In many marriages, many husbands and wives seem to live like strangers or co-tenants with one another. The marital relationship which is supposed to be a unifying factor among the wife, husband and the children is found to run short of these expectations. Homes are no longer what they are supposed to be, married adults no longer seem to find satisfaction with their marital relationship and instead, many married partners find it more convenient to discuss their problems, fears and aspirations with people outside or their relationship, rather than communicating with their spouses.

A number of studies have been carried out to investigate the influence of communication on marital adjustment. Omojola (1993) stated that it is likely that poor communication and mar- 
marital dissatisfaction mutually reinforces each other. Esere (2000) similarly observed that the degree to which spouses are able to communicate their feelings in an understandable manner and do things together, go a long way in determining their degree of adjustment.

Ogunsanmi (2008) identified education as a variable that affects the marital adjustment of adults. Further, this researcher found that adults with higher education levels were more likely to be more stable in marriage than those with less education. Another issue raised was the religion of the married partners. It was discovered that religion has an influence on marriage. Intra-faith adults were discovered to be more well-adjusted than inter-faith ones. Age is another important variable in marital adjustment; it was shown that age had a significant impact on marital adjustment.

According to Munroe (2003), marriage is a serious affair naturally meant for adults who are psychologically mature or endowed with the ability to shoulder the responsibility of the adults or the expectations of marriage. Communication is very important in marriage; it is the key to a healthy relationship. It allows for expression of love and affection between married couples. According to Olagunju and Eweniyi (2002), marriage without communication is likely to crumble. The promotion of good communication in marriage is a major solution to many cases of marital discord in our society. Through good communication styles, couples try to resolve their conflicts thus promoting marital unity. Also, Akpan (2002) believed that effective marital communication is the life-wire that links a husband and wife together, strengthens the bond of relationship and pervades all activities in the home. In marriage, quite a number of problems arise as a result of lack of communication.

Idowu and Esere (2007) opined that more than half of failed relationships (marital) are due to the fact that there is severe lack of communication among couples. When two persons come into a marriage relationship, there is need for adjustment if the relationship is to be successful (Jawondo, 2009). It has been observed that most marriages have a potential to be successful, but fail because the spouses fail to learn new methods of coping with the new world they just entered into. Many marriages in society are casualties, crushed and brought to a sudden end, only because married adults are not well-informed, prepared and equipped about the expectations of marriage. Ogunsanmi (2008) opined that adjustment is one of the eight most pressing social problems of the present world.

Adjustment between spouses does not happen automatically; the married adults need to work assiduously to achieve a satisfying level of adjustment that is needed for a workable relationship. It is also discovered that the inability of the adults to make the necessary adjustments that are needed in a relationship brings tragedies in many marriages. A study by Gary (1977) revealed that the age of the adult at marriage, whether early or late, has a negative effect on their marital adjustment. They submitted that the various physical and psychological changes that occur in marriage are seen to be an ardous task for those that married early. As such, this study investigates the relationship between marital adjustment and communication styles among married adults in Ilorin, Kwara State. 


\section{Problem}

The home is the nucleus of the society and marriage is the major avenue whereby the society is populated by the number of children that are born into such marriages, thus marital dissatisfaction produces a negative multiplier effect on the society. Many marriages have ended in divorce or in a passive relationship.

Many marriages breakdown very soon after an elaborate wedding. According to Olayiwola (2009), many marriages breakdown weeks or months after a wedding. Young couples who feel happy and dance from dusk to dawn during their marriage ceremony turn out to call "the sugar in their tea" a "torn in their life". When there is no marital satisfaction, there is a problem with raising and nurturing children, which may lead to an increase in the rate of juvenile delinquency in the society and a lack of peace. Adeoti (2000) opined that communication is the major source of marital conflict. He observed that communication is often the missing link in an unhappy marriage. This is because of the importance of communication to a marital relationship. It is more important now to work on the communication skills between a husband and wife. So many problems escalate when there is no communication, and many problems are resolved when there is communication.

Marital adjustment is a lifelong process. From the earliest days of marriage, one has to give serious consideration to mate selection. This understanding of the individual traits of the spouse is an ongoing process in marriage because even if two people know each other before or at the time of marriage, there is a possibility that people change during the life cycle. Marital adjustment and a call for maturity that accepts and understands growth and development in the spouse is needed. If this growth is not experienced and realized fully, the death of the marital relationship is inevitable (Shweta, 2013).

Some researchers like Esere (2008) and Oniye (2008) discovered that even in homes with children, there might still be constant conflicts between the parents. While each of the stated problems may be a source of conflict, the role communication plays in resolving them is crucial. However various researchers have studied communication styles and other marital adjustment variables. Salifu (2009), for example, studied styles of communication and marital adjustment of educated couples in Ankpa, Kogi state and found that couples who established a good and sound communication style was likely to have pleasant relationship. Also, Oladun (2012) worked on obstacles and suggested solutions for effective communication in marriage as expressed by married adults in Kogi state. The findings revealed that marriage involves honesty and a sincere expression of feedings and this would help to reduce the high rate of divorce cases in society. Filani (1985) researched the effects of communication skill training on marriage adjustment and styles of communication of educated couples in Ogbomoso. He was able to find out that poor communication leads to a breakdown in marriages. To the best of the researchers' knowledge, no study has been carried out on the relationship between marital adjustment and communication styles among married adults in Ilorin, Kwara State, Nigeria. 


\section{Research Questions}

The following questions were raised for this study:

1. What are the marital adjustments of married adults in Ilorin, Kwara State?

2. What are the communication styles of married adults in Ilorin, Kwara State?

\section{Research Hypotheses}

The following null hypotheses were postulated for the study:

1. There is no significant relationship between marital adjustment and communication styles among married adults in Ilorin, Kwara State based on age.

2. There is no significant relationship between marital adjustment and communication styles among married adults in Ilorin, Kwara State based on gender.

3. There is no significant relationship between marital adjustment and communication styles among married adults in Ilorin, Kwara State based on years in marriage.

4. There is no significant relationship between marital adjustment and communication styles among married adults in Ilorin, Kwara State based on educational status.

\section{Methods}

Research Design

The research design that was adopted for this study is a descriptive survey of correlational type. The descriptive survey is the research method that enables a researcher to obtain the opinion of representative sample of a target population so as to infer the attitude of the entire population.

\section{Population, Sample and Sampling Procedure}

The population of this study comprised all married adults in Ilorin, Kwara State. Daramola (2006) defined the sampling procedure as a systematic process employed to select a required proportion of a target population. For the purpose of this study, two Local Government Areas were selected from the three Local Government Areas (LGAs) in Ilorin metropolis. From each of the selected LGAs, respondents were drawn from public organizations: schools, hospitals, and local government headquarter offices using a multi-stage sampling technique. 
In the first stage, purposive sampling was used to select two LGAs in the Ilorin metropolis. A purposive sampling technique is a procedure in which a researcher purposively selects certain groups as samples because of their relevance to the investigation under consideration (Da ramola, 2006). Ilorin West and Ilorin South were selected for the study. At the second stage, a dip-hat simple random technique was used to select the locations where the respondents for the study were found. They were: Ministries, Secretariat, Schools (one private and one public) from each of the sampled LGAs.

At the third stage, stratified sampling was used to place the newly married adults into strata based on the variables under study which were: age, gender, religion and employment status. From each of the stratum, the researcher used simple random sampling to select 40 married adults from each of the selected ministries, 40 from the secretariat and 20 from a private school and 20 from a public secondary school; a total of 120 newly married adults were selected from each of the LGAs for the study. A grand total of 240 married adults were selected from the Ilorin area.

\section{Instrumentation}

According to Oyewo (2003), instrumentation is the selecting or developing of measuring devices and method appropriate to a given evaluation and research problem. Instrumentation is a way of developing measuring devices and methods for gathering data by the educational researcher (Olayiwola, 2007).

The instrument used in collecting data for this study is a researcher-constructed questionnaire tagged "Relationship between Marital Adjustment and Communication Styles Questionnaire" (RMACSQ). The questionnaire is a 20 item instrument, subdivided into three major sections: A, B and C. Section A contains the background information of the respondents such as gender, age, years in marriage, and educational status. Section B consists of twenty (10) items focusing on the marital adjustment of married adults while section $\mathrm{C}$ consists of the communication styles of married adults.

The respondents are expected to respond to the 20 items on the relationship between marital adjustment and communication styles using the four-point Likert types rating scale of SA - Strongly Agree, A - Agree, D - Disagree, SD - Strongly Disagree.

\section{Psychometric Properties of the Instrument}

An instrument must possess certain qualities or properties for it to be valid. Three of these qualities are validity; reliability and usability. These properties are regarded as psychometric properties.

Validity: One of the most important psychometric properties of research instrument is validity. Validity, according to Olayiwola (2007), is the extent to which an instrument or test measures what it purports to measure Content and Face validity of the instrument were established by given the initial draft to five experts in the Department of Counsellor Education, 
University of Ilorin. The experts made corrections, and gave comments and views which were taken into consideration when preparing the final draft of the questionnaire. The general consensus of the experts was that the instrument was valid in its content and its relevance to the study.

Reliability: Reliability has to do with the consistency and stability of an instrument. Reliability is the consistency, accuracy, stability and trustworthiness of a measuring instrument or score obtained, that is, how far the same instrument would give the same score on different occasions or with different sets of equivalent items under the same condition (Adegboyega, 2018).

The reliability of the instrument was determined by a test re-test reliability method. The instrument was given to a sample of twenty selected married adults outside the sample scope but within the same geographical location. The instrument was given to the same set of newly married adults within an interval of four weeks. Pearson's Product Moment Correlation was used to compare the scores from the two administrations, the result yielded 0.76. This suggested that there was correlation between the two sets of scores. Hence, the instrument is judged reliable and useable.

\section{Procedure for Data Collection}

The instrument was administered by the researcher to selected married adults in some selected LGAs in Ilorin, Kwara State. An instant filling out of the questionnaire was encouraged for easy and quick retrieval of the completed questionnaires.

\section{Method of Data Analysis}

The data obtained was subjected to statistical analysis. The statistical methods are both descriptive and inferential. In testing the hypotheses, Pearson Product Moment Correlation (PPMC) was employed to test the null hypotheses at a 0.05 alpha level. PPMC is the reliable statistical method to test for relationship between variables of study.

\section{Results}

Research Question 1: What are the marital adjustments of married adults in Ilorin, Kwara State? 
Table 1:

Mean and Rank Order on Marital Adjustment of Married Adults

\begin{tabular}{llll}
\hline Item & & & \\
No. & As a married adult, I: & Mean & Rank \\
\hline 1 & meet demands of marriage life & 3.57 & $1^{\text {st }}$ \\
6 & raise children with my spouse & 3.47 & $2^{\text {nd }}$ \\
7 & manage my finances with my spouse & 3.18 & $3^{\text {rd }}$ \\
2 & meet the overwhelming expectation of in-laws & 3.10 & $4^{\text {th }}$ \\
9 & maintain a stable emotional state & 3.09 & $5^{\text {th }}$ \\
8 & improve my work involvement & 2.72 & $6^{\text {th }}$ \\
10 & live together with my in-laws & 2.71 & $7^{\text {th }}$ \\
3 & cope with spouse's job demands & 2.56 & $8^{\text {th }}$ \\
4 & live far away from my parents & 2.43 & $9^{\text {th }}$ \\
5 & meet sexual demands of my spouse & 2.16 & $10^{\text {th }}$ \\
& & & \\
\hline
\end{tabular}

Table 1 presents the marital adjustment of married adults. The table shows that most of the items have mean scores greater than 2.50 (average point) regardless of the order of ranking. This indicates that most of the items indicate a mode of marital adjustment of married adults. It can be concluded that there was a high level of marital adjustment among married adults in Ilorin, Kwara State.

Research Question 2: What are the communication styles of married adults in Ilorin, Kwara State?

Table 2:

Mean and Rank Order of Marital Adjustment on Married Adults

\begin{tabular}{llcc}
\hline Item No. I communicate with my husband as follows: & Mean & Rank \\
\hline $9 \quad$ I speak directly to my spouse & 3.64 & $1^{\text {st }}$ \\
10 & I monopolize discussion with my spouse & 3.13 & $2^{\text {nd }}$ \\
5 & I speak calmly and in clear tone & 3.11 & $3^{\text {rd }}$ \\
$1 \quad$ I keep silent to express lack of interest in a particular situation & 3.06 & $4^{\text {th }}$ \\
$6 \quad$ The tone of my voice does not matter when I am discussing & & \\
$\quad$ with my partner & 2.92 & $5^{\text {th }}$ \\
$2 \quad$ I usually tell my spouse everything that happens during & 2.83 & $6^{\text {th }}$ \\
$\quad$ his/her absence & 2.69 & $7^{\text {th }}$
\end{tabular}


3 I hugged my spouse

8 I groan to vent my anger towards my spouse

5 I wink my eyes to communicate with my spouse
$2.29 \quad 8^{\text {th }}$

$2.06 \quad 9^{\text {th }}$

$1.7510^{\text {th }}$

Table 2 presents the communication styles of married adults. The table shows that most of the items have mean scores greater than 2.50 (average point) regardless of order of ranking. This indicates that most of the items indicate good communication styles of married adults. It can be concluded that there were good communication styles among married adults in Ilorin, Kwara State.

\section{Hypotheses Testing}

Four hypotheses were postulated in the course of this study. All hypotheses were tested using PPMC at a 0.05 alpha level.

Hypothesis 1: There is no significant relationship between marital adjustment and communication styles among married adults in Ilorin, Kwara State on the basis of age.

Table 3:

Pearson ' $r$ ' showing the Relationship between Marital Adjustment and Communication Styles among Married Adults based on Age

\begin{tabular}{lcccccccc}
\hline Variable & N & Mean & SD & df & $\begin{array}{l}\text { Cal. r- } \\
\text { value }\end{array}$ & $\begin{array}{l}\text { Tab r- } \\
\text { value }\end{array}$ & Sig. & Decision \\
\hline $\begin{array}{l}\text { Marital } \\
\text { adjustment }\end{array}$ & 240 & 54.91 & 3.95 & 238 & 0.003 & 0.195 & .630 & $\begin{array}{l}\text { Not } \\
\text { Rejected }\end{array}$ \\
$\begin{array}{l}\text { Communication } \\
\text { styles }\end{array}$ & 240 & 53.61 & 3.88 & & & & & \\
\hline
\end{tabular}

Table 3 shows that the calculated r-value is 0.003 while the table $r$-value is 0.195 . Since the cal $r-$ value is less than the Table r-value, hypothesis 1 is hereby not rejected. This implies that, there is no significant relationship between marital adjustment and communication styles among married adults in Ilorin, Kwara State on the basis of age. 
Hypothesis 2: There is no significant relationship between marital adjustment and communication styles among married adults in Ilorin, Kwara State on the basis of gender.

Table 4:

Pearson ' $r$ ' showing the Relationship between Marital Adjustment and Communication Styles among Married Adults based on Gender

\begin{tabular}{lcccccccc}
\hline Variable & N & Mean & SD & df & $\begin{array}{l}\text { Cal. r- } \\
\text { value }\end{array}$ & $\begin{array}{l}\text { Tab r- Sig. } \\
\text { value }\end{array}$ & Decision \\
\hline $\begin{array}{l}\text { Marital } \\
\text { adjustment }\end{array}$ & 240 & 54.91 & 3.95 & 238 & 0.190 & 0.195 & .004 & $\begin{array}{l}\text { Not } \\
\text { Rejected }\end{array}$ \\
$\begin{array}{l}\text { Communication } \\
\text { styles }\end{array}$ & 240 & 53.61 & 3.88 & & & & & \\
\hline
\end{tabular}

Table 4 shows that the calculated r-value is 0.190 while the Table r-value is 0.195 with 238 degrees of freedom. Since the cal r-value is less than the table r-value, hypothesis 2 is hereby not rejected. This implies that, there is no significant relationship between marital adjustment and communication styles among married adults in Ilorin, Kwara State on the basis of gender.

Hypothesis 3: There is no significant relationship between marital adjustment and communication styles among married adults in Kwara State on the basis of years in marriage.

Table 5:

Pearson ' $r$ ' showing a Relationship between Marital Adjustment and Communication Styles among Married Adults based on Years in Marriage

\begin{tabular}{lcccccccc}
\hline Variable & N & Mean & SD & df & $\begin{array}{l}\text { Cal. r- } \\
\text { value }\end{array}$ & $\begin{array}{l}\text { Tab r- } \\
\text { value }\end{array}$ & Sig. & Decision \\
\hline $\begin{array}{l}\text { Marital } \\
\text { adjustment }\end{array}$ & 240 & 54.91 & 3.95 & 238 & $0.198^{*}$ & 0.195 & .002 & Rejected \\
$\begin{array}{l}\text { Communication } \\
\text { styles }\end{array}$ & 240 & 53.61 & 3.88 & & & & & \\
\hline
\end{tabular}

- $\quad$ Significant $p<0.05$ 
Table 5 shows that the calculated r-value is 0.198 while the table r-value is 0.195 with 238 degrees of freedom. Since the cal r-value is higher than the table r-value, hypothesis 3 is hereby rejected. This implies that, there is a significant relationship between marital adjustment and communication styles among married adults in Kwara State on the basis of years in marriage.

Hypothesis 4: There is no significant relationship between marital adjustment and communication styles among married adults in Ilorin, Kwara State on the basis of educational status.

Table 6:

Pearson ' $r$ ' showing a Relationship between Marital Adjustment and Communication Styles among Married Adults based on Educational Status

\begin{tabular}{lcccccccc}
\hline Variable & N & Mean & SD & df & $\begin{array}{l}\text { Cal. r- } \\
\text { value }\end{array}$ & $\begin{array}{l}\text { Tab r- Sig. } \\
\text { value }\end{array}$ & Decision \\
\hline $\begin{array}{l}\text { Marital } \\
\text { adjustment }\end{array}$ & 240 & 54.91 & 3.95 & 238 & 0.093 & 0.195 & .152 & $\begin{array}{l}\text { Not } \\
\text { Rejected }\end{array}$ \\
$\begin{array}{l}\text { Communication } \\
\text { styles }\end{array}$ & 240 & 53.61 & 3.88 & & & & & \\
\hline
\end{tabular}

Table 6 revealed that the calculated r-value is 0.093 while the table r-value is 0.195 with 238 degrees of freedom. Since the cal r-value is less than the table r-value, hypothesis 3 is hereby not rejected. This implies that, there is no significant relationship between marital adjustment and communication styles among married adults in Ilorin, Kwara State on the basis of educational status.

\section{Discussion}

The findings of the study revealed that there was a high level of marital adjustment among married adults in Ilorin, Kwara State. This was supported by Esere (2006) which stressed that marriage is an avenue for adults to meet the lifelong satisfaction of enduring affection and companionship. It also revealed that there were good communication styles among married adults in Ilorin, Kwara State. This also corroborates the findings of Iwokwagh, Onasanya and Onasanya (2010) who pointed that effective communication between couples would help addressing many issues which could have resulted into conflict in the family. Their findings also 
indicated that peace at a family level is a pathway for the enduring peace of a nation which in turns brings about national development. Also, Akpan (2002) believed that effective marital communication is the life wire that links husbands and wives together. It also strengthens the bond of the relationship and pervades all activities in the home.

Another finding revealed that there was no significant relationship between marital adjustment and communication styles among married adults in Ilorin, Kwara State on the basis of age. This indicated that age does not have a relationship between marital adjustment and communication styles of married adults. This was in line with the opinion of Ogunsanmi (2008) and Yahaya (2008) who both revealed that age at marriage does have a substantial impact on marital satisfaction and stability, however, they also opined that there is need for more studies into the effect of this variable on marital adjustment, especially in conjunction with communication styles. Also, Ogunsanmi (2008) opined that age is another important variable in marital adjustment as it was shown that age had a significant impact on marital adjustment. According to Oniye (2004), age, that is chronological years one has lived in life, has a significant effect on the stability and adjustment of marriage.

Finding also revealed that there was no significant relationship between marital adjustment and communication styles among married adults in Ilorin, Kwara State on the basis of gender. This shows that being male or female would not have any significant impact on marital adjustment and communication styles of married adults. This was supported by Gary (1977) which revealed that the gender of the adult at marriage, whether male or female has no negative effect on their marital adjustment. They submitted that the various physical and psychological changes that occur in marriage are seen to be an arduous task for those that married early. Thus, the early married men and women may not be matured or well prepared both physically and emotionally to cope with the demands or the adjustment in marriage.

Another finding revealed that there was a significant relationship between marital adjustment and communication styles among married adults in Ilorin, Kwara State on the basis of years in marriage. This indicated that the years married adults have spent in their marital life would determine their marital adjustment and communication styles. This was in line with Noller (1998) and Adegboyega (2021) which opined that couples reported having higher quality styles of communication two years into their marriage than immediately following the beginning of their relationship while the style of communication can and does change with the length of the marriage.

Findings also revealed that there was no significant relationship between marital adjustment and communication styles among married adults in Ilorin, Kwara State on the basis of educational status. This indicated that educational attainments of married adults do not have any relationship with their marital adjustment and communication styles. This corroborated the study of Ogunsanmi (2008) which identified education as a variable that affects the marital adjustment of adults. The study stressed that adults with higher education were more likely to be more stable in marriage than those with less education. 


\section{Conclusion}

Based on the findings of the study, it was therefore concluded that:

There was a high level of marital adjustment among married adults in Ilorin, Kwara State. Married adults in Ilorin Kwara State adopt good communication styles in marriage. There was no significant relationship between marital adjustment and communication styles of married adults in Kwara State based on age, gender and educational status. There was a significant relationship between marital adjustment and communication styles among married adults in Kwara State on the basis of years of marriage.

\section{Recommendations}

Based on the findings of this study, it was recommended that:

- Seminars and conferences should be organized for married adults in other LGAs to enlighten them on the challenges of marital relationship. This would enable them to adjust and communicate better in their new home.

- The intending couples should also go for pre-marital counselling programs that are handled and coordinated by professional marriage counsellors so that they can acquire the necessary knowledge and skills that will assist them in their marriage.

- Parents of the married adults should also give them support during the early years in marriage. This will go a long way in assisting the married couples to be able to tap from the experiences of their parents in marriage.

- The married adults should also understand themselves, and the styles of communication that can work well for their marriage because good communication styles in marital life will foster better adjustment in marriage.

- Religious leaders should also encourage married adults, and teach them the tenet of their religion on marriage. This can be done in terms of a sermon on their wedding day which will based on the challenges of marriage and how to cope with it. 


\section{References}

Adegboyega, L. O. (2018). Influence of achievement motivation on Nigerian undergraduates' attitude towards examination. International Journal of Instruction, 11(1), 77-88.

Adegboyega, L. O. (2021): Influence of spousal communication on marital conflict resolution as expressed by married adults in Ilorin metropolis, Kwara State: Implications for counselling practice. Canadian Journal of Family and Youth, 13(1), 71-83.

Adeyemi, E. (1991). Causes of divorce and separation as perceived by married students in tertiary institutions in Ilorin, unpublished B.ED. Project submitted to the Department of Guidance and Counselling, University of Ilorin.

Akpan, C.P. (2002). Marital communication in E. Uwe \& Obto, A. (Eds), Marriage counselling: Issues and Solutions (PP23-30). Calabar: Pyramid computer services.

Anyakoha, E.U. \& James, M.B. (2004). Conflict resolution practices of couples within families. In Borno state of Nigeria.

Ariyo, A.M (2005). Some determinants and consequences of marital instability in Ogun State: a case study, Nigeria Journal of Applied psychology, 8/9,2/1.54 -69.

Clark, S.C. (1995). Advance report of final divorce statistics, 1989 and 1990. Monthly Vital Statistics Report, 43 (Suppl.8) 1- 20.

Cohn S.M. (2010). Marriage Communication. Tetrieved April 10, 2010 from http://www.faimilynamic.com. Communication and conflict management in the family: Implications for national development. The Nigerian Journal of Guidance and Counselling, 15 (1), 22-33.

Daramola, S.O. (2006). Research and statistical methods in education for students and researchers in tertiary institution. Ilorin: Bamitex Printing and Publishing.

DeFrain, J. (2000). Marriage and the Family: Diversity and Strength. Mayfield Publishing Company, Mountain View; CA.

Ekot, M.O \& Usoro, C. (2006). Marital conflict and resolution strategies of couples in Abak Local Government Area of Akwa Ibom State.

Esere, M.O. (2000). The effect of cognitive restructuring in resolving marital conflicts among selected couples in Ilorin, Nigeria. Journal of Applied Psychology 6 (1), 87 - 98.

Esere, M.O. (2002). Approaches to marital therapy. The Nigerian Journal of Guidance and Counselling 8 (1), $61-85$. 
Esere, M.O. (2008). Communication in marital relationship. Inl. A yahaya, M.O. Esere, J.O. Ogunsanmi, \& A.O. Oniye. Marriage, sex and family counselling. Ilorin: Unilorin Press. (pp. $81-102$ ).

Filani, T.O. (1985). An experimental study of communication skill training and cognitive restructuring on the marital adjustment of some Nigerian. Unpublished doctoral thesis. Department of Guidance and counselling, university of Ilorin.

Gary, R.L. (1977). Age at marriage and marital satisfaction. Journal of marriage and the family. 39 (3), 493, 493 - 495

Gordon, K.C. Baucom, D.H., Epstein, N. Burneth, C.K. \& Rankin, L.A. (1999). Interaction between marital standards and communication patterns: How does it contribute to marital adjustment? The Journal of m marital and family therapy 10. 123.

Habeeb. M. (2005) Indices of marital stability as perceived by married man and woman in Ilorin metropolis, unpublished M.ED. Project, University of Ilorin, Ilorin, Nigeria.

Idowu, A.I. \& Esere, M.O (2007). Communication in counselling: A multidimensional perspective. Ilorin: Timsal Publishers.

Iwokwagh, N, S., Onasanya, S, A. \& Onasanya, E. O (2010). Communication and conflict management in the family: Implications for national development. The Nigerian Journal of Guidance and Counselling, 15 (1), 22-33.

Jawondo, I.A (2009). A paper presented on empowering women and youth for peace in Nigeria at Catholic Diocese Church, Ilorin, Kwara State.

Munroe, M. (2003). Understanding the woman's communication style: Promoting positive Muslim marital relations. A Journal of Sound Islamic Thoughts, 1 (1), 46-51.

Noller, P. (1998). Misunderstanding in marital communication: A study of adult's non-verbal communication. Journal of Personality and Social Psychology, vol. 39.

Ogunsanmi, J. O. (2008) Encouraging marital adjustment the African way in L.A. Yahaya, M.O. Esere; J. O. Ogunsanmi \& A. O. Oniye marriage, sec and family counselling, Ilorin: unilorin press p. $161-162$.

Oladun, S (2012). Obstacles and suggested solutions to effective communication in marriage as expressed by married adults in Kogi state. Unpublished master thesis. University of Ilorin, Ilorin, Nigeria.

Olagunju, O. P. \& Eweniyi, G. B. (2002). Communication: A strategy in conflict resolution among organisational workers. The Counsellor, 19(1), 66-78. 
Olayiwola, A.O. (2007). Procedure in educational research. Kaduna: Klingo (Nig) Limited.

Omojola, E.B. (1993). Getting the best out of your marriage. Ibadan: Agape Publication.

Omotosho, J.A. (1994). Principles of interpersonal relationship. Unpublished manuscript. Department of Guidance and Counselling, University of Ilorin.

Oniye, A. O. (2002). Ilorin male and polygamy. Article in the emirate spring vol. 1 No. 3, p. 17. Publication, Ilorin emirate student Union, University of Ilorin, Ilorin.

Oniye, A. O. (2004). Marital and family counselling. In A.I, Idowu (Ed).Guidance and counselling in Education. Ilorin: Indemac Publishers (Nig). Ltd.

Oniye, A. O. (2008). Concept and types of marriage. In Yahaya, L.A.; Esere, M.O; Ogunsanmi, J. O. \& Oniye, A. O (1 $1^{\text {st }}$ edition). "Marriage, sex and family counselling”. Ilorin: Unilorin Press.

Oyewo, B.A. (2003). Attitude of Couples to STD/ HIV and AIDS. Preventive programmes in Surulere Local Government Area of Lagos State. Unpublished M.Ed. project. University of Ibadan, Ibadan.

Roper Organisation (1990). Public attitude and behaviour. Retrieved from Study Info for Pew Research Center: American Trends Panel Wave 61 (Roper \#31117211) | Roper iPoll Roper Center for Public Opinion Research (cornell.edu)

Salifu, A. A. (2009) Styles of communication and marital adjustment of educated couple in Ankpa, Kogi state. Unpublished master thesis, university of Ilorin, Ilorin, Nigeria.

Shweta, N. (2013) Effect of marital adjustment in middle-age Adults. Department of Home science, Bamasthali university, Rajasthan, India.

Tolkien, J. R. R. (2005). Memes of love, sex and marriage. Retrieved leonf@perspectivity. Net on $13^{\text {th }}$ January 2005 . University life as a function of relationships with parents [Electronic University: Department of Anthropology.

Verderber, K.S., \& Verderber, R.F. (2004). Communicate. Retrieved from http//www.amazon.com on $5^{\text {th }}$ Feb., 2004.

Wiate L. J. \& Gallagher, M. (2000). The case of marriage: Why married people are happier, healthier and better off financially. New York: Doubleday.

Yahaya. L.A. (2008). Choice of spouse. In L.A. Yahaya, M.O. Esere, J.O. Ogunsanmi \& A.O. Oniye. Marriage, Sex and Family Counselling. Ilorin: Unilorin Press. 